\title{
The Efforts in Improving Students Mathematics Learning Outcomes Through Problem Based Learning (PBL) in Grade XII of SMK Tritech Informatika Medan
}

\author{
Tengku Taufik Azhar (a*), Edy Surya (a) \\ Department of Mathematics Education \\ a) State University of Medan \\ Medan, Indonesia \\ Corresponding Email : azta89@gmail.com
}

\begin{abstract}
In this research describes the implementation of Problem Based Learning (PBL) to improve student learning outcomes of grade XII Vocational School (SMK) Tritech Informatika Medan. This research aimed to know the improvement and the achievement of mathematics learning outcomes of students through problem based learning (PBL) in grade XII of Vocational School (SMK) Tritech Informatika Medan. This research was a classroom action research in which there were three cycles in which each cycle consisted of planning, implementation, observation, and reflection. The object of this research was on the effort in improving students' mathematics learning outcomes through problem based learning (PBL).The subjects in this study were students of class XII TKJ 2 SMK Tritech Informatika Medan in the academic year 2017/2018 which amounted to 24 students. The results in cycle I showed that students still had the low result, with a rate of $62.5 \%$ mastery learning and in the cycle II, students' mastery learning reached $83.33 \%$. It had not met the expected criteria yet because students' learning achievement had not reached $85 \%$ yet, so the process was necessary to be continued and improved.In Cycle III, students' learning achievement reached $87,5 \%$ or there were 21 students from 24 students who completed the study individually. Then, the results of this research showed that learning by using problem based learning (PBL) in SMK Tritech Informatika Medan could improve students' learning outcomes.
\end{abstract}

Keywords: Learning Outcomes, Problem Based Learning (PBL).

\section{INTRODUCTION}

Education wasessential, for the purpose of education wasnone other than to develop mature thinkers and for them to be able to use the knowledge in real life. One way that could be done to achieve the goal of education was through mathematics learning. Mastery of mathematics will play a role in the mastery of science globally, because by learning mathematics students were trained to develop a logical, critical, creative, systematic, responsible and have a good personality and skills to solve problems in everyday life.

However, in reality there were still many students who have not been able to achieve the expected achievement from learning. Mathematics lesson was now still regarded as a difficult lesson for students, resulting in less than optimal learning outcomes. It happened because students do not have the basic competencies that students should have.

One of the learning models that will affect the learning process was the problem-based learning model. Problem based learning was a model of learning that makes the problem as a starting point in starting learning and was designed as a learning process that required students to gain the ability to solve problems, independence and good participation skills to gain a new knowledge.

In the learning process, teacher played a role in helping students to study the presented problems. Teacher also encouraged students to be able to collect a number of information relevant to the problem, and performed a number of experiments to get a clarity of the problems encountered and obtained solutions in solving the problem.

Problem based learning model could help the students in being aware ofthe problems around them, and could increase student's learning activity in the classroom by not only listening, recording, and memorizing what the teacher had explained but also the students will be actively involved in their learning either in communicating their mathematical ideas as well as in presenting their learning outcomes.

This is also confirmed by Frida that problem-based learning (PBL) was so well applied that it could serve as an alternative in innovative mathematics learning [1]. In addition,Padmavathy stated that by adopting PBL methods in teaching, mathematics teachers could create creative thinkers, important decision makers, problem solvers that could provide many opportunity for learners to learn more about engagement and could increase students' active participation, motivation and interest among the learners [2].

In the PBL procedure, students were placed into small groups and presented with an open ended problems to solve or questions to answer. These prompts were designed to activate and build upon prior knowledge, and were almost always related to real-world scenarios. The other students, in addition to the teacher, served as scaffolds for developing one's knowledge base [3]. 
PBL method was a learning mentality of how we were questioning the life and how we imitated what we learnt [4]. PBL as beneficial not only in overcoming the difficulties but also in discovering the method followed during the process of reaching the solutions. Learning in PBL was realized over the problems. Instead of investigating only one simple solution, students interpreted the problem, brought new knowledge together, defined the possible solutions, evaluated the options and interpreted the results. In PBL method, by taking the existing knowledge related to problem into consideration, students determined what kind of knowledge they need, dida research and discussed the new knowledge gained in cooperative group environment. This situation continued until finding solution for the problem [5]. This method provided students with having knowledge about what was learnt and why [6].

By adopting PBL methods in teaching, Math teachers could create creative thinkers, key decision-makers, enormous problem solvers provide learners with greater opportunity to learn more engagement and to increase students' active participation, motivation and interests among learners.

In learning mathematics, especially in thelesson of theory of opportunity studied by students of class XII, often found students who have difficulty in solving the problems presented. After the author made a preliminary observation to the school and interviewed the mathematics teacher at SMK Tritech Informatika Medan, he said that the constraints in providing the theory of opportunity lesson to the studentswere that sometimes students got confused in understanding and finding out how to start the solution, especially on the problem which was the application stage. Based on this background the authors were interested to conduct research with the title: "The Efforts in Improving Students'Mathematics Learning Outcomes Through Problem Based Learning (PBL) in Grade XII of SMK Tritech Informatika Medan."

\section{RESEARCH METHODS}

This research was in the form of action research class which emphasized on the activity, by testing an idea into practice or real situation in micro scale, which expected that the activity could improve the learning result.

In accordance with this type of research, that was classroom action research, this research had several stages which were a cycle. Each cycle was implemented in accordance with the changes to be achieved. This research was planned to be carried out for four cycles.

In more detail, the procedure for conducting classroom action research based on the flow according to the PGSM project team can be described as follows [7]:

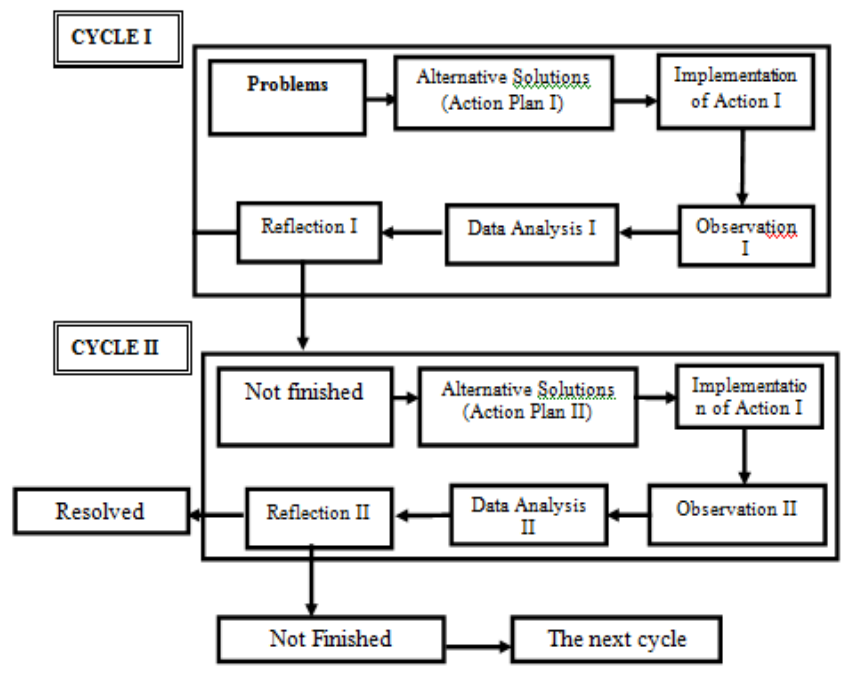

Figure 1: Procedures for the implementation of Class Action Research based on the flow according to the PGSM Project Trainer Team

Data Collection Tools

The tools used in collecting data on research were test, interview and observation.

1. Test

The test was in the form of a description test. Testing was done four times, the result of learning test in cycle I (after finishing cycle I), test result of learning cycle II (after cycle II), test result of learning cycle III (after cycle III). To validate the test the researchers asked for the help of one lecturer majoring in mathematics State University of Medan and two teachers in the field of mathematics study SMK Tritech Informatika Medan.

2. Interview

The questions given during the interview were directed to find out the constraints faced by the students during the learning and the difficulties of students in solving the given problems.

3. Observation

Observations made werethe monitoring of all teaching activities and changes that occured at the time of the execution of actions.

Data Analysis Technique

Data analysis in this research was done in several stages:

1. Data Reduction

Data reduction was done after the data was collected. Reduction activities included categorization and classification of data. Once classified, the data were grouped and then proceeded to the inference. This reduction activity aimed to look at the errors in student's answers in solving social arithmetic problems and what actions were taken to correct them.

2. Data Exposure

Data exposure was done by displaying the units of information systematically. With the exposure of that information, researchers will be able to draw conclusions 
easily. To clarify the analysis, the research data was presented in a narrative form and equipped with tables.

\section{Data Conclusions}

In this activity, conclusions were drawn based on the results of research that has been done. The basis for the implementation of the next cycle and the need for subsequent cycles to continue on the alleged problem were drawn from the conclusions.

$>$ Calculating students' mastery level

According to Nurkancana, the category of mastery of students were as follows [8]:

Table of Students Mastery Level

\begin{tabular}{|c|l|}
\hline $\begin{array}{c}\text { Level of } \\
\text { Mastery }\end{array}$ & \multicolumn{1}{c|}{ Criteria } \\
\hline $90 \%-100 \%$ & Very high ability \\
$80 \%-89 \%$ & High ability \\
$65 \%-79 \%$ & Moderate ability \\
$55 \%-64 \%$ & Low ability \\
$0 \%-54 \%$ & Very low ability \\
\hline
\end{tabular}

It was said that student reached mastery level if the student at least reached the moderate criteria.

$>$ To determine student's learning completeness (individual), it could be calculated by using the equation as proposed by Depdikbud that was [9]:

$$
\mathrm{KB}=\frac{T}{T_{1}} x 100 \%
$$

Information:

KB : Mastery learning

$\mathrm{T} \quad$ :Score student obtained

$\mathrm{T}_{1} \quad$ : Total score

Each student wasconsidered to complete the learning (individual completeness) if the proportion of correct answers students were more than or equal to $65 \%$.

From the description above, itcould be seen whether the students who had not finished learning or who had completed the study individually.

Furthermore, it could also be known whether the mastery of learning had been achieved clasically, that was seen from the percentage of students who had completed the study formulated as follows:

$$
\mathrm{PKK}=\frac{X}{N} x 100 \%
$$

Information:

PKK : Percentage of Classical Completeness

$\mathrm{X}$ : Number of students whose $\mathrm{KB}$ value was more than or equal to $65 \%$

$\mathrm{N} \quad$ : Number of research subject

A class was defined complete if the percentage of classical completeness reached $\geq 85 \%$.

In this research, the learning outcomes increased if the percentage of $\mathrm{KB}$ and PKK obtained by students were increasing from the given initial test, up to the tests performed on each cycle and at least $85 \%$ of the students got the test results of learning outcomes for $\geq 6.5$ and to know the difficulties of students. Then it could be seen from the results of the conducted tests as well as from interviews that were done in every end of the cycle.

\section{RESEARCH RESULTS}

\section{- Cycle I}

From the result of learning action by using problem based learning $(\mathrm{PBL})$ in cycle I, the learning completeness level equal to $62,5 \%$ was obtained. However, the result was not asexpected. Hence, improvement of learning to improve the result of student learning in solving problem at theory of opportunity lesson was needed.

In addition to the implementation of these actions there were some weaknesses, including that there were students who remained unable to understand the lesson taught, from the researchers themselves theyfelt that the action done was not maximum. During the first cycle, researchers had also found weaknesses among them, giving researchers less opportunity to ask questions, sometimes explaining the problem too quickly, less involving students to be more active and a less conducive classroom atmosphere. Due to the problems that had not been resolved and the results of the learning test in the first cycle had not completed in a classical way, the learning will proceed to cycle II.

Table 1. Description of Student's Capacity in Cycle I

\begin{tabular}{|c|l|l|l|l|}
\hline $\begin{array}{c}\text { Percentage of } \\
\text { Mastery }\end{array}$ & $\begin{array}{c}\text { Ability } \\
\text { Level }\end{array}$ & $\begin{array}{c}\text { Number } \\
\text { of } \\
\text { Student } \\
\mathrm{s}\end{array}$ & $\begin{array}{c}\text { Percentag } \\
\text { e Number } \\
\text { of } \\
\text { Students }\end{array}$ & $\begin{array}{c}\text { Comple } \\
\text { tion }\end{array}$ \\
\hline \begin{tabular}{c|c|c|}
$90 \%-100 \%$ \\
$80 \%-89 \%$
\end{tabular} & Very high & 3 & $12,5 \%$ & \\
$65 \%-79 \%$ & High & 5 & $20,83 \%$ & $62,5 \%$ \\
$55 \%-64 \%$ & Loderate & 7 & $29,17 \%$ & (incom \\
$0 \%-54 \%$ & 3 & $12,5 \%$ & plete) \\
\hline \multicolumn{6}{|c|}{ Total } & 6 & $25 \%$ & \\
\hline
\end{tabular}

\section{- Cycle II}

From the result of learning action by using problem based learning (PBL) in cycle II, learning mastery level equal to $83,33 \%$ was obtained, the result was not yet in accordance with what was expected, so that the improvement of learning to maximize the result of student learning in solving problemsin the theory of opportunity remained necessary.

In addition to the implementation of these actions, there were still some weaknesses, including that there were students who remained not understanding the material being delivered, from the researchers themselves felt the action that had been done was not maximum. During the second cycle of action, researchers also found other weaknesses, in some cases the researchers delivered the explanation of the problem too fast, also less involving students to be more active and less conducive classroom atmosphere. Due to the problems that had not been resolved and the results of the learning test in cycle II had not completed in a classical way, the learning will be continued to cycle III. 
Table 2. Description of Students' Capactiy in Cycle II

\begin{tabular}{|c|c|c|c|c|}
\hline $\begin{array}{c}\text { Percentageof } \\
\text { Mastery }\end{array}$ & $\begin{array}{c}\text { Ability } \\
\text { Level }\end{array}$ & $\begin{array}{c}\text { Number } \\
\text { of } \\
\text { Students }\end{array}$ & $\begin{array}{l}\text { Percentage } \\
\text { of Number } \\
\text { of Students }\end{array}$ & $\begin{array}{c}\text { Completi } \\
\text { on }\end{array}$ \\
\hline $90 \%-100 \%$ & Very high & 7 & $29,17 \%$ & \\
\hline $80 \%-89 \%$ & High & 6 & $25 \%$ & $83,33 \%$ \\
\hline $65 \%-79 \%$ & Moderate & 7 & $29,16 \%$ & (incompl \\
\hline $55 \%-64 \%$ & Low & 1 & $4,17 \%$ & ete) \\
\hline $0 \%-54 \%$ & Very low & 3 & $12,5 \%$ & \\
\hline \multicolumn{2}{|c|}{ Total } & 24 & $100 \%$ & \\
\hline
\end{tabular}

\section{- Cycle III}

From the results of data analysis above, it was shown that there was an increase in test results from the previous learning cycle. By using realistic learning in cycle III, comprehension level of $87,5 \%$ was obtained. The results had finally met the expected criteria and completed classically. So it could be concluded that learning by using problem based learning $(\mathrm{PBL})$ could improve student learning outcomes on the lesson of theory of opportunity.

Table 3. Description of Students' Capactiy in Cycle III

\begin{tabular}{|c|l|c|c|c|}
\hline $\begin{array}{c}\text { Percentage } \\
\text { of Mastery }\end{array}$ & \multicolumn{1}{|c|}{$\begin{array}{c}\text { Ability } \\
\text { Level }\end{array}$} & $\begin{array}{c}\text { Number } \\
\text { of } \\
\text { Students }\end{array}$ & $\begin{array}{c}\text { Percentage } \\
\text { of Number } \\
\text { of Students }\end{array}$ & $\begin{array}{c}\text { Comple } \\
\text { tion }\end{array}$ \\
\hline $90 \%-100 \%$ & Very high & 9 & $37,5 \%$ & \\
$80 \%-89 \%$ & High & 8 & $33,33 \%$ & $87,5 \%$ \\
$65 \%-79 \%$ & Moderate & 4 & $16,67 \%$ & (comple \\
$55 \%-64 \%$ & Low & 3 & $12,5 \%$ & te) \\
$0 \%-54 \%$ & Very low & 0 & $0 \%$ & \\
\hline \multicolumn{2}{|r|}{ Total } & 24 & $100 \%$ & \\
\hline
\end{tabular}

\section{Research Results Study}

Through learning mathematics by using problembased learning achieved the mastery learning in classical. Based on the result of research, after given action in cycle I, the completion of classical learning equal to $62,5 \%$ was obtained, whereas in the test of learning result of II, learning completeness classically equal to $83,33 \%$ was obtained, and in learning test result III, classical learning completeness equal to $87.5 \%$ was obtained.

From cycle I to cycle II there was an increase in learning mastery by $20.83 \%$, in cycle II to cycle III also occurred a $4.17 \%$ increase of improvement in the learning outcomes. In cycle III, the completeness of classical learning was achieved with 21 students reaching the learning completeness level, and 3 students $(12,5 \%)$ who had not yet reached learning mastery. This indicated that learning by using problem based learning (PBL) could improve student learning outcomes on the lesson of theory of opportunity.

Research showed that the delivery of theory of opportunity lesson could be made successful by using problem-based learning (PBL) method. Thus, this study had shown that learning with problem-based learning (PBL) could improve student learning outcomes on the lesson of theory of opportunity.

\section{CONCLUSION}

Based on the results of research that had been described, it could be concluded:

1. Through learning mathematics with problem-based learning (PBL) on theory of opportunity lesson, mastery learning in a classical manner was achieveable. Based on the results of the research, after the action was given in the first cycle, the completeness of classical learning by $62.5 \%$ was obtained, while on the test of learning results II, learning completeness in classical of $83.33 \%$ or increased by $20.83 \%$, from cycle I was obtained and on the test of learning result III learning mastery by classical equal to $87,5 \%$ or increase equal to $4,17 \%$ from cycle II was obtained. So that problem-based learning (PBL) on the theory of opportunity lesson could improve student learning outcomes in class XII TKJ 2 Vocational School (SMK) Tritech Informatika Medan.

2. Through mathematics learning by applying problem based learning on the opportunity theorylesson could improve student learning outcomes.

3. In the delivery of action in the first cycle there were 15 people who achieved learning mastery and 9 students who did not. In cycle II there were 20 people who achieved learning mastery and 4 students who did not. In the third cycle there were 21 people who achieved learning mastery and 3 students who did not.

4. Through the delivery of the theory of opportunity lesson in problem-based learning (PBL), students in class XII TKJ 2 in SMK Tritech Informatika Medan felt enthusiastic in learning because the problems that were given was relevant with everyday life and every student was active and free to determine the solution of each question according to their own thoughts. Furthermore, teachers and students drew conclusions of thecore idea/ principle of the encountered problems.

\section{REFERENCES}

[1] Simorangkir, Frida. 2014. Perbedaan kemampuan pemecahan masalah matematis siswa yang diajarkan dengan pembelajaran berbasis masalah dan pembelajaran konvensional. Jurnal Saintech Vol. 06 - No.4 Desember 2014. FKIP Universitas Quality

[2] Padmavathy, RD 2013. Effectiveness of Problem Based Learning In Mathematics. International Multidisciplinary e-Journal Vol-II, Issue-I, Jan. -2013 .

[3] Schmidt, H. G., Loyens, S. M., van Gog, T., \& Paas, F. (2007). Problem-based learning is compatible with human cognitive architecture: Commentary on Kirschner, Sweller, and Clark (2006). Educational Psychologist, 42, 91-97.

[4] Duch, B. J. (2001). Writing problems for deeper understanding. In The Power of Problem-Based Learning: A Practical „How To" for Teaching Undergraduate Courses in Any Discipline, edited by B. Duch, S. E. Groh, and D. E. Allen, pp. 47-53.

[5] Peterson, F., \& Eaguest, D. (1998). Learning to teach primary science through problem based learning. Science Education. 82, 215-237. 
[6] Chin, C., \& Chia, L. (2004). Problem-based learning: Using students' questions to drive knowledge construction. Science Education, 88, 707-727.

[7] Tim Pelatihan Proyek PGSM. 1999. Penelitian Tindakan Kelas (Classroom Action Reseach). Departemen Pendidikan dan Kebudayaan Direktorat Jenderal Pendidikan Tinggi Proyek Pengembangan Guru Sekolah Menengah ( Secondary School Teacher Development Project) IBRD LOAN No. 3979-IND
[8] Nurkancana, Wayan dan Sunartana. 1992. Evaluasi Hasil Belajar. Surabaya: Usaha Nasional.

[9] Trianto, 2011, Model Pembelajaran Terpadu Konsep,Strategi Dan Implementasinya Dalam Kurikulum Tingkat Satuan Pendidikan (KTSP), Jakarta : Bumi Aksara. 